\title{
Recommendations for the management of critically ill adult patients with COVID-19
}

\author{
Silvio A. Namendys-Silvat,2* and Guillermo Domínguez Cherit
}

${ }^{1}$ Instituto Nacional de Cancerología, Department of Intensive Therapy; ${ }^{2}$ Instituto Nacional de Ciencias Médicas y Nutrición Salvador Zubirán, Sub-directorate of Critical Medicine. Mexico City, Mexico

\begin{abstract}
Except for pregnant women, the management of critically ill patients with COVID-19 during the pandemic includes the standard procedures that are used for any patient that requires to be attended to at the intensive care unit, as well as limited administration of crystalloid solutions, orotracheal intubation, invasive mechanical ventilation in the event of patient clinical deterioration, and muscle relaxants continuous infusion only if necessary. Non-invasive mechanical ventilation and high-flow oxygen therapy are not recommended due to the generation of aerosol (associated with risk of viral spread among health personnel), and neither is extracorporeal membrane oxygenation or the use of steroids. So far, there is no specific antiviral treatment for patients with COVID-19, and neither are there results of controlled trials supporting the use of any.
\end{abstract}

KEY WORDS: Coronavirus. COVID-19. Intensive care. Critical care.

\section{Recomendaciones de tratamiento para pacientes adultos graves con COVID-19}

\section{Resumen}

Con excepción de las mujeres embarazadas, el manejo de los pacientes adultos graves con COVID-19 durante la pandemia incluye los procedimientos estándar que se llevan a cabo en cualquier paciente que requiere atención en la unidad de cuidados intensivos, así como la administración limitada de las soluciones cristaloides, la intubación orotraqueal, la ventilación mecánica invasiva ante deterioro clínico del paciente y la relajación muscular en infusión continua sólo cuando sea necesaria. No se recomienda la ventilación mecánica no invasiva, la oxigenoterapia de alto flujo debido a la generación de aerosol (asociado con riesgo de propagación del virus entre el personal de salud), la oxigenación por membrana extracorpórea ni el empleo de esteroides. Hasta el momento no hay tratamiento antiviral específico para pacientes con COVID-19 ni resultados de estudios controlados que avalen su uso.

PALABRAS CLAVE: Coronavirus. COVID-19. Cuidados intensivos. Terapia intensiva.

\footnotetext{
Correspondence:

*Silvio A. Ñamendys-Silva

E-mail: snamendys@gmail.com

Date of reception: 20-03-2020

Date of acceptance: 13-04-2020

DOI: 10.24875/GMM.M20000375

Gac Med Mex. 2020;156:246-248

Contents available at PubMed

www.gacetamedicademexico.com

0016-3813/@ 2020 Academia Nacional de Medicina de México, A.C.. Published by Permanyer. This is an open access article under the CC BY-NC-ND license (http://creativecommons.org/licenses/by-nc-nd/4.0/).
} 


\section{Introduction}

By March 19, 2020, 209,839 cases of coronavirus disease (COVID-19) had been confirmed worldwide, with global mortality associated with this cause being less than $5 \%(8778 / 209,839) .{ }^{1}$ Approximately $4.7 \%(2087 / 44,672)$ of patients with COVID-19 had developed a severe form of the disease, and mortality in seriously ill patients was around $49 \%$ $(1023 / 2087) .^{2}$ At that time, total number of confirmed cases in Mexico was 164, with a mortality rate lower than $1 \%(1 / 164)$, and there were 448 suspected cases under investigation in different states of the Mexican Republic. In the ensuing weeks, the number of confirmed cases has increased. ${ }^{3}$ The purpose of this work is to present the main recommendations for the treatment of seriously ill adult patients with COVID-19, with the exception of pregnant women.

\section{Main recommendations}

- The management of critically ill patients with COVID-19 during the pandemic is the same that is provided to any critically ill patient that requires attention at the intensive care unit (ICU), i.e., standard treatment. ${ }^{4}$

- The definitions of sepsis, septic shock ${ }^{5}$ and acute respiratory failure syndrome ${ }^{6}$ do not change. The same operational definitions that apply to seriously ill patients without COVID-19 admitted to the ICU should be used.

- Administration of supplemental oxygen to patients with severe acute respiratory infection, respiratory distress, hypoxemia or shock is intended to achieve an oxygen saturation $>94 \%{ }^{4}$

- Hospitalized patients with COVID-19 require close surveillance and monitoring. Using the National Early Warning Score (NEWS 2) is recommended in order to early identify those patients with high risk of in-hospital complications. ${ }^{4}$

- Performing a complete blood count, blood chemistry, venous or arterial blood gas testing, serum electrolyte testing and electrocardiogram when the patient is admitted to the ICU is suggested. If the tests were carried out in the emergency department and the patient clinical condition has not changed when transferred to the ICU, there is no need to repeat them. ${ }^{4}$
- If imaging studies such as chest X-ray or tomography were performed in the emergency department, there is no need to repeat them. Once the patient is in the ICU, follow-up can be carried out with lung ultrasound.

- If the patient shows clinical deterioration and there is any evidence of organ failure during his/ her stay at the ICU, the necessary biomarkers should be assessed according to the affected organ or system. ${ }^{4}$

- Restrictively administering crystalloid solutions is recommended. ${ }^{4,5}$

- If the patient has risk factors for bacterial infections, intravenous antibiotic treatment should be started according to the epidemiological profile of the hospital during the first hour of assessment of the seriously ill patient with operational criteria consistent with sepsis. ${ }^{5}$

- For the time the influenza season continues, considering the use of oseltamivir at the usual dose and interval is suggested, according to the result of the rapid test performed at the time of patient assessment. ${ }^{4}$

- In the emergency department or in hospitalization, patients with type I acute respiratory failure can receive 10 to $15 \mathrm{~L} /$ minute of supplemental oxygen through a mask with a reservoir. If the patient clinical condition deteriorates, all necessary equipment should be prepared to perform orotracheal intubation and initiate invasive mechanical ventilation, which should be adjusted according to lung protective strategies. ${ }^{4}$

- Health personnel should carry out orotracheal intubation after putting on all the protective equipment for high-risk procedures (orotracheal intubation, orotracheal tube change, cardiopulmonary resuscitation). Using a videolaryngoscope is recommended. ${ }^{6}$

- Invasive mechanical ventilation should be started with a tidal volume of 4 to $6 \mathrm{~mL} / \mathrm{kg}$ of predicted weight, following the recommendations for lung protection. $^{7}$

- Deep sedation should be used if necessary, in order to avoid invasive mechanical ventilation-associated damage, always following the recommendations for sedation and analgesia for seriously ill patients. ${ }^{5,6}$

- Early changing the patient to the prone position should be considered if he/she continues with hypoxemia despite all adjustments to the ventilator. ${ }^{8}$ 
- Muscular relaxant continuous infusion should not be routinely used, but according to each patient's clinical conditions. ${ }^{4,9}$

- It is important to avoid ventilator disconnection, which results in loss of positive end-expiratory pressure, atelectasis and aerosol generation. ${ }^{4}$

- Non-invasive mechanical ventilation and highflow oxygen therapy are not recommended due to the generation of aerosol and the associated risk of viral spread among health personnel., ${ }^{6,10,11}$ The only scenario where these measures might be used is when a seriously ill patient requires invasive ventilatory support and the necessary equipment is not available; in those cases, the patient should preferably be moved to a cubicle with negative pressure.

- Extracorporeal membrane oxygenation is not recommended given that recent reports suggest high mortality in patients with COVID-19 treated with this form of organ support, which should not be used in hospitals that are not reference or high-volume centers and whose personnel has no experience with this procedure..$^{12,13}$

- Using steroids is not recommended. ${ }^{14}$

- So far, there is no specific antiviral treatment for patients with COVID-19 or results of controlled trials supporting the use of any; the antivirals that are being proposed are under experimentation and are not part of the standard treatment for patients with COVID-19.

- The use of vasopressor drugs to maintain mean blood pressure $\geq 65 \mathrm{~mm} \mathrm{Hg}$ is only indicated if hypovolemia has been excluded and mean blood pressure has not improved despite resuscitation with crystalloid solutions. Norepinephrine is the first-line vasopressor. ${ }^{4,5}$

- If data consistent with tissue hypoperfusion are identified despite adequate resuscitation with crystalloids or vasopressor use, using dobutamine should be considered. ${ }^{4,5}$

All the described recommendations are subject to change according to updates published in national or international journals.

\section{Conflict of interests}

The authors declare that they have no conflicts of interest.

\section{Funding}

The authors received no sponsoring to carry out this article.

\section{Ethical disclosures}

Protection of people and animals. The authors declare that no experiments were performed on humans or animals for this study.

Right to privacy and informed consent. The authors declare that no patient data appear in this article.

\section{References}

1. World Health Organization [website]. Coronavirus disease (COVID-2019) situation reports. Switzerland: WHO; 2020.

2. The novel coronavirus pneumonia emergency response epidemiology team. The epidemiological characteristics of an outbreak of 2019 novel coronavirus diseases (COVID-19)-China. Zhonghua Liu Xing Bing Xue Za Zhi. 2020;2:113-122.

3. Secretaría de Salud de México [website]. Comunicado técnico diario nuevo coronavirus en el mundo (COVID-19). México: SSa; 2020.

4. World Health Organization. Clinical management of severe acute respiratory infection when COVID-19 is suspected. Switzerland: WHO; 2020.

5. Rhodes A, Evans LE, Alhazzani W, Levy MM, Antonelli M, Ferrer R, et al. Surviving sepsis campaign: international guidelines for management of sepsis and septic shock: 2016. Intensive Care Med. 2017;43:304-377.

6. Cheung JC, Ho LT, Cheng JV, Cham EYK, Lam KN. Staff safety during emergency airway management for COVID-19 in Hong Kong. Lancet Respir Med. 2020;8:e19.

7. ARDS Definition Task Force, Ranieri VM, Rubenfeld GD, Thompson BT, Ferguson ND, Caldwell $E$, et al. Acute respiratory distress syndrome: The Berlin Definition. JAMA. 2012;307:2526-2533.

8. Guérin C, Reignier J, Richard JC, Beuret P, Gacouin A, Mercier E, et al. Prone positioning in severe acute respiratory distress syndrome. N Engl J Med. 2013;368:2159-2168

9. The National Heart, Lung, and Blood Institute PETAL Clinical Trials Network, Moss M, Huang DT, Brower RG, Ferguson ND, Ginde AA, et al. Early neuromuscular blockade in the acute respiratory distress syndrome. N Engl J Med. 2019;380:1997-2008.

10. Ñamendys-Silva SA. Respiratory support for patients with COVID-19 infection. Lancet Respir Med. 2020;S2213-2600:30110-30117.

11. Murthy S, Gomersall CD, Fowler RA. Care for critically ill patients with COVID-19. JAMA. 2020;10:1001.

12. MacLaren G, Fisher D, Brodie D. Preparing for the most critically ill patients with COVID-19: the potential role of extracorporeal membrane oxygenation. JAMA. 2020;10:1001.

13. Brandon MH. COVID-19, ECMO, and lymphopenia: a word of caution. Lancet. 2020;8:24.

14. Russell CD, Millar JE, Baillie JK. Clinical evidence does not support corticosteroid treatment for 2019-nCoV lung injury. Lancet. 2020;395:473-475. 